\title{
Prevalence of carbapenemases among high-level aminoglycoside-resistant Acinetobacter baumannii isolates in a university hospital in China
}

\author{
YANHONG WANG $^{1 *}$, MIN SHEN $^{1 *}$, JINGNI YANG $^{1}$, MIN DAI $^{3}$, YAOWEN CHANG $^{2}$, \\ CHI ZHANG ${ }^{2}$, GUANGXIN LUAN ${ }^{1}$, BAODONG LING ${ }^{2}$ and XU JIA ${ }^{1}$ \\ ${ }^{1}$ Non-Coding RNA and Drug Discovery Laboratory; ${ }^{2}$ Small Molecule Drugs Sichuan Key Laboratory, Institute of \\ Materia Medica; ${ }^{3}$ School of Laboratory Medicine, Chengdu Medical College, Chengdu, Sichuan 610500, P.R. China
}

Received August 28, 2015; Accepted September 1, 2016

DOI: $10.3892 /$ etm.2016.3828

\begin{abstract}
The prevalence of aminoglycoside resistant enzymes has previously been reported and extended-spectrum $\beta$-lactamase among Acinetobacter baumannii. To track the risk of multidrug-resistant $A$. baumannii, the present study aimed to determine the prevalence of carbapenemases in high-level aminoglycoside resistant $A$. baumannii over two years. A total of 118 strains of A. baumannii were consecutively collected in the First Affiliated Hospital of Chengdu Medical College, Chengdu, China. These isolates were investigated on the genetic basis of their resistance to aminoglycosides. The results showed that $75(63.56 \%)$ isolates were high-level resistant to aminoglycosides, including gentamicin and amikacin (minimum inhibitory concentration, $\geq 256 \mu \mathrm{g} / \mathrm{ml})$. Aminoglycoside-resistant genes $\operatorname{ant}\left(2^{\prime \prime)}-I a, \operatorname{aac}\left(6^{\prime}\right)-I b, \operatorname{aph}\left(3^{\prime}\right)-I a, \operatorname{aac}(3)-I a, \operatorname{aac}(3)-I I a\right.$, armA, rmtA, rmtB, rmtC, rmtD, rmtE, rmtF, rmtG, rmtH and $n p m A$, and carbapenem-resistant genes $b l a_{\text {OXA-23 }}, b l a_{\text {OXA-24 }}$, $b l a_{\mathrm{OXA}-51}, b l a_{\mathrm{OXA}-58}, b l a_{\mathrm{SIM}}, b l a_{\mathrm{IMP}}, b l a_{\mathrm{NDM}-1}$ and bla $_{\mathrm{KPC}}$, were analyzed using polymerase chain reaction. The positive rate of ant(2")-Ia, aac(6')-Ib, aph(3')-Ia, aac(3)-Ia and $a a c(3)-I I a$ was $66.95,69.49,42.37,39.83$ and $14.41 \%$, respectively. arm $A$ was present in $72.0 \%(54 / 75)$ of $A$. baumannii isolates with
\end{abstract}

Correspondence to: Professor Xu Jia, Non-Coding RNA and Drug Discovery Laboratory, Chengdu Medical College, 783 Xindu Road, Chengdu, Sichuan 610050, P.R. China

E-mail: jiaxu@cmc.edu.cn

Professor Baodong Ling, Small Molecule Drugs Sichuan Key Laboratory, Institute of Materia Medica, Chengdu Medical College, 783 Xindu Road, Chengdu, Sichuan 610050, P.R. China

E-mail: lingbaodong@cmc.edu.cn

*Contributed equally

Key words: Acinetobacter baumannii, aminoglycosides, $16 \mathrm{~S}$ ribosomal RNA methylase, carbapenemases, multilocus sequence typing high-level resistance to aminoglycosides. The remaining nine $16 \mathrm{~S}$ ribosomal RNA methlyase genes ( $r m t A, r m t B, r m t C$, $r m t D, r m t E, r m t F, r m t G, r m t H$ and $n p m A)$ and aminoglycoside-modifying enzyme gene $a a c\left(6^{\prime}\right)-I b-c r$ were not detected. Among the 54 armA-positive isolates, the prevalence of the carbapenem resistant $b l a_{\text {OXA-23 }}$ and $b l a_{\text {OXA-51 }}$ genes was 79.63 and $100 \%$, respectively. $\operatorname{armA}$, $\operatorname{ant}\left(2^{\prime \prime}\right)-I a$ and $a a c\left(6^{\prime}\right)-I b$ were positive in 43 isolates. The results of multilocus sequence typing revealed 31 sequence types (STs) in all clinical strains. Among these STs, the high-level aminoglycoside-resistant A. baumannii ST92, which mostly harbored $b l a_{\text {OXA-23 }}$, was the predominant clone (29/75). In conclusion, A. baumannii harboring carbapenemases and aminoglycoside-resistant enzymes are extremely prevalent in western China, emphasizing the need to adopt surveillance programs to solve the therapeutic challenges that this presents.

\section{Introduction}

Acinetobacter baumannii is an important opportunistic pathogen that causes various types of human infections and has become a primary cause of nosocomial infections because of its broad antimicrobial resistance (1-3). Aminoglycosides, a type of broad-spectrum antibiotics, continue to serve an important role in treating serious infections caused by gram-negative bacteria (4). However, aminoglycoside resistance of $A$. baumannii has rapidly increased and given rise to more challenges in the clinical treatment of infections (5).

A. baumannii shows resistance to aminoglycosides since functional aminoglycosides can be modified by various aminoglycoside-modifying enzymes, including acetyltransferases, phosphotransferases and nucleotidyltransferases, into non-functional forms in the bacteria (6). In addition, aminoglycoside antibiotics bind specifically to the A-site of $16 \mathrm{~S}$ ribosomal (r)RNA in the $30 \mathrm{~S}$ small subunit and interfere with the decoding of mRNA to inhibit protein synthesis (7). In addition, at least ten $16 \mathrm{~S}$ rRNA methylase genes (armA, rmtA, $r m t B, r m t C, r m t D, r m t E, r m t F, r m t G, r m t H$ and $n p m A)$ have been identified (8-12). These 16S rRNA methylases, which lead to the high-level resistance of various aminoglycosides, can easily transfer to other bacteria since their genes are typically 
present on plasmids (13). Therefore, the emergence and spread of such bacteria should be carefully monitored. Since the $16 \mathrm{~S}$ rRNA methylases are key factors in the aminoglycoside resistance of A. baumannii, the investigation of the acquisition of $16 \mathrm{~S}$ rRNA methylase genes by clinical isolates is important for the prevention and treatment of their infections (14).

Aminoglycosides and carbapenems represent the class of antimicrobials that are used to treat A. baumannii infections. Aminoglycoside antibiotics are frequently ineffective against strains of A. baumannii; however, combinations of aminoglycosides and carbapenems can produce synergistic effects to treat infected patients $(15,16)$. Previously, it has become evident that the outgrowth of carbapenem-resistant isolates has resulted in it being difficult to treat A. baumannii infections. One of the most important mechanisms underlying the resistance of carbapenems is the production of carbapenemases in A. baumannii (17). Class D oxacillinases (OXA type) are the primary cause of prevalence in A. baumannii strains (18). In addition, causes stem from class B $\beta$-lactamases (metallo- $\beta$-lactamases) and Klebsiella pneumoniae Carbapenemase (KPC) producers. These carbapenemases are a diverse group of $\beta$-lactamases that are active against the carbapenems, resulting in their limited clinical use.

Several studies have documented the co-existence of bla $a_{\mathrm{OXA}-23}$ and armA in multidrug resistant A. baumannii isolates (19-22). For example, Doi et al (19) first discovered that two of five A. baumannii isolates coproduced OXA-23 $\beta$-lactamase and ArmA in North America in 2007. In addition, further cases were reported in Korea (20,23), India (24), France (25), Bulgaria (26), Italy (27), Latvia (28), East Africa (29), Yemen (30), Japan (31), Brunei (32), Egypt (33) and China $(21,34,35)$. The authors of the present study previously determined that extended-spectrum $\beta$-lactamase and 16S rRNA methylase are coproduced in A. baumannii (36). However, the high-level resistance to aminoglycosides, coupled with carbapenem resistance in A. baumannii, were not reported over the 4-year period in China, particularly in western China.

The aim of the present study was to explore the high-level resistance mechanisms against aminoglycosides, and to investigate the presence of carbapenemases among strains of A. baumannii. In addition, the relatedness of aminoglycoside- and carbapenem-resistant strains, determined through epidemiologic examination, is described. To the best of our knowledge, the present study is the first to document the emergence of $A$. baumannii producing $b l a_{\text {OXA-23 }}$ and $b l a_{\text {OXA-51 }}$ carbapenemase-encoding genes among armA $16 \mathrm{~S}$ rRNA methylases at a university hospital in western China. Furthermore, the results aim to emphasize that the dearth of appropriate treatments remains a primary concern regarding multidrug-resistant infections.

\section{Materials and methods}

Clinical isolates. A total of 118 strains of A. baumannii were consecutively collected in a university hospital of western China between February 2012 and July 2013. Rapid species identification was performed by polymerase chain reaction (PCR), as reported within 'Resistance gene amplification' and previously described (37). A. baumannii was identified and confirmed if the following two PCR products were yielded: A 425-bp internal control amplicon corresponding to the recA gene of Acinetobacter spp., and a 208-bp fragment of the 16S rRNA intergenic spacer region of A. baumannii (38). Non-baumannii species of Acinetobacter, which yielded the 425-bp product alone, were excluded in this study. Isolates were obtained from specimens including sputum, secretion, lavage fluids, blood and other specimens. All strains were stored at $-80^{\circ} \mathrm{C}$. Bacteria were grown on tryptose agar or Mueller-Hinton broth. No amplicons were obtained with bacteria belonging to other genera.

Antimicrobial susceptibility testing. The minimum inhibitory concentrations (MICs) of amikacin and gentamicin (Sangon Biotech Co., Ltd., Shanghai, China) for A. baumannii were determined on Mueller-Hinton agar plates by agar dilution according to the protocol recommended by the Clinical and Laboratory Standards Institute (39). MICs of meropenem and imipenem (Sangon Biotech Co., Ltd.) were tested in high-level aminoglycoside-resistant isolates. The results were interpreted according to the CLSI guidelines. Escherichia coli [American Type Culture Collection (ATCC) 25922] and A. baumannii (ATCC 19606) (ATCC, Manassas, VA, USA) were used as quality control strains.

Resistance gene amplification. The aminoglycoside-modifying enzyme genes and the 16S rRNA methylase genes were detected by PCR. Total DNA was extracted by boiling at $95^{\circ} \mathrm{C}$ for $15 \mathrm{~min}$. After centrifugation at $13,000 \mathrm{x} g$ for $10 \mathrm{~min}$ to pellet the debris, the supernatant was stored at $-20^{\circ} \mathrm{C}$ for further assays. PCR was performed in a total volume of $50 \mu \mathrm{l}$ containing $0.2 \mathrm{mM}$ of each deoxynucleotide, $0.5 \mu \mathrm{M}$ of each primer (Table I), 2.5 units Taq polymerase (Takara Bio, Inc., Dalian, China) and $5 \mu 110 \mathrm{X}$ buffer (Thermo Fisher Scientific, Inc., Waltham, MA, USA). Primers listed in Table I were synthesized by Sangon Biotech Co., Ltd.. The PCR thermal cycling conditions were as follows: Initial denaturation at $94^{\circ} \mathrm{C}$ for 5 min in order to obtain partial activation of Taq polymerase; then, the number of cycles was increased to 30 , each consisting of a denaturation step for $30 \mathrm{sec}$ (at $94^{\circ} \mathrm{C}$ ), an annealing step for $30 \mathrm{sec}$ (at $55^{\circ} \mathrm{C}$ for $\operatorname{armA}, r m t A$, $r m t B, r m t C, r m t D, r m t E, r m t F, r m t G, r m t H$ and $n p m A$, at $53^{\circ} \mathrm{C}$ for $\operatorname{ant}\left(2^{\prime \prime}\right)-I a$, aph(3')-Ia, $\operatorname{aac}(3)-I a$ and $\operatorname{aac}(3)-I I a$, and at $56^{\circ} \mathrm{C}$ for $a a c\left(6^{\prime}\right)-I b$ ) and an extension step for $30 \mathrm{sec}$ (at $72^{\circ} \mathrm{C}$ ). Each amplification experiment included a blank containing the reagent except for target DNA. The products were electrophoresed in $1 \%$ agarose gels and visualized under ultra-violet light (Bio-Rad Laboratories, Inc., Hercules, CA, USA). All a ac(6')-Ib PCR products were directly sequenced and compared with the published nucleotide (NC_005327.1).

Genes coding for classes A, B and D carbapenemases were investigated among high-level aminoglycoside-resistant isolates by PCR. The genes encoding class A, such as Klebsiella pneumoniae carbapenemase gene (bla $\left.a_{\mathrm{KPC}}\right)(40)$, class B, such as the metallo- $\beta$-lactamase genes $\left[\right.$ bla $_{\mathrm{IMP}}(41)$, bla $_{\mathrm{VIM}-1}(42)$, $b l a_{\mathrm{SIM}}(43)$ and $\left.b l a_{\mathrm{NDM}-1}(44)\right]$ and class D, such as CHDLs [bla OXA-23 $_{\text {(45), } \text { bla }_{\text {OXA-24 }}(45), \text { bla }_{\text {OXA-51 }} \text { (46) and bla }}$ OXA-58 $\left.(47)\right]$, were also analyzed using PCR. Reaction conditions of PCR were as follows: $94^{\circ} \mathrm{C}$ for $5 \mathrm{~min}$; and 30 cycles of $94^{\circ} \mathrm{C}$ for $30 \mathrm{sec}, 56^{\circ} \mathrm{C}$ for $30 \mathrm{sec}$ and $72^{\circ} \mathrm{C}$ for $30 \mathrm{sec}$; followed by a final extension at $72^{\circ} \mathrm{C}$ for $5 \mathrm{~min}$. 
Table I. Primers used in the present study for polymerase chain reaction detection.

\begin{tabular}{|c|c|c|c|}
\hline Primer & Target & Oligonucletides (5' to $3^{\prime}$ ) & Expected size (bp) \\
\hline armA forward & $\operatorname{arm} A$ & AGGTTGTTTCCATTTCTGAG & 591 \\
\hline $\operatorname{arm} A-\mathrm{R}$ & & ТСТСТТССАТТСССТТСТСС & \\
\hline$r m t A$ forward & $r m t A$ & CTAGCGTCCATCCTTTCCTC & 635 \\
\hline$r m t A-\mathrm{R}$ & & TTTGCTTCCATGCCCTTGCC & \\
\hline$r m t B$ forward & $r m t B-$ & CCCAAACAGACCGTAGAGGC & 585 \\
\hline$r m t B-\mathrm{R}$ & & CTCAAACTCGGCGGGCAAGC & \\
\hline$r m t C$ forward & $r m t C$ & CGAAGAAGTAACAGCCAAAG & 711 \\
\hline $\mathrm{rmtC}-\mathrm{R}$ & & ATCCСААСАТСТСТСССАСТ & \\
\hline$r m t D$ forward & $r m t D$ & CGGCACGCGATTGGGAAGC & 401 \\
\hline$r m t D-\mathrm{R}$ & & CGGAAACGATGCGACGAT & \\
\hline$r m t E$ forward & $r m t E$ & ATGAATATTGATGAAATGGTTGC & 823 \\
\hline$r m t E-\mathrm{R}$ & & TGATTGATTTCCTCCGTTTTTG & \\
\hline$r m t F$ forward & $r m t F$ & GCGATACAGAAAACCGAAGG & 589 \\
\hline$r m t F-\mathrm{R}$ & & ACCAGTCGGCATAGTGCTTT & \\
\hline$r m t G$ forward & $r m t G$ & AAATACCGCGATGTGTGTCC & 250 \\
\hline$r m t G$ reverse & & ACACGGCATCTGTTTCTTCC & \\
\hline$r m t H$ forward & $r m t H$ & GCTTAAACCCGCTGATGCT & 332 \\
\hline $\mathrm{rmtH}$ reverse & & AAACCAGGTGGCGTAGTGC & \\
\hline npmA forward & npmA & GGAGGGCTATCTAATGTGGT & 371 \\
\hline npmA reverse & & GCCCAAAGAGAATTAAACTG & \\
\hline $\operatorname{ant}(2 ")-$ Ia forward & $\operatorname{ant}(2 ")-I a$ & GCTTACGTTGTCCCGCATTT & 215 \\
\hline $\operatorname{ant}(2 ")-$ Ia reverse & & CCTTGGTGATCTCGCCTTTC & \\
\hline $\operatorname{aph}\left(3^{\prime}\right)-I a$ forward & $\operatorname{aph}\left(3^{\prime}\right)-I a$ & CGAGCATCAAATGAAACTGC & 623 \\
\hline $\operatorname{aph}\left(3^{\prime}\right)-I a$ reverse & & GCGTTGCCAATGATGTTACAG & \\
\hline aac(3)-Ia forward & $a a c(3)-I a$ & GACATAAGCCTGTTCGGTT & 372 \\
\hline aac(3)-Ia reverse & & CTCCGAACTCACGACCGA & \\
\hline aac(3)-IIa forward & $a a c(3)-I I a$ & ATGCATACGCGGAAGGC & 822 \\
\hline $\operatorname{aac}(3)-$ IIa reverse & & TGCTGGCACGATCGGAG & \\
\hline$a a c\left(6^{\prime}\right)-I b$ forward & $a a c\left(6^{\prime}\right)-I b$ & AAGCGTTTTAGCGCAAGAGT & 366 \\
\hline$a a c\left(6^{\prime}\right)-I b$ reverse & & GCGTGTTTGAACCATGTACA & \\
\hline$O X A-23$ forward & $O X A-23$ & GATCGGATTGGAGAACCAGA & 501 \\
\hline$O X A-23$ reverse & & ATTTCTGACCGCATTTCCAT & \\
\hline$O X A-24$ forward & $O X A-24$ & CAAGAGCTTGCAAGACGGACT & 420 \\
\hline$O X A-24$ reverse & & TCCAAGATTTTCTAGCRACTTATA & \\
\hline$O X A-51$ forward & $O X A-51$ & TAATGCTTTGATCGGCCTTG & 353 \\
\hline$O X A-51$ reverse & & TGGATTGCACTTCATCTTGG & \\
\hline OXA-58 forward & $O X A-58$ & TCGATCAGAATGTTCAAGCGC & 530 \\
\hline$O X A-58$ reverse & & ACGATTCTCCCCTCTGCGC & \\
\hline$N D M-1$ forward & $N D M-1$ & TCTCGACATGCCGGGTTTCGG & 475 \\
\hline$N D M-1$ reverse & & ACCGAGATTGCCGAGCGACTT & \\
\hline$K P C$ forward & $K P C$ & GCTCAGGCGCAACTGTAAGT & 823 \\
\hline$K P C$ reverse & & GTCCAGACGGAACGTGGTAT & \\
\hline$I M P$ forward & $I M P$ & CTACCGCAGAGTCTTTG & 587 \\
\hline$I M P$ reverse & & AACCAGTTTTGCCTTACCAT & \\
\hline SIM forward & SIM & TACAAGGGATTCGGCATCG & 570 \\
\hline SIM reverse & & TAATGGCCTGTTCCCATGTG & \\
\hline
\end{tabular}

Multilocus sequence typing (MLST). MLST was performed according a the previously described A. baumannii MLST study (48). Briefly, internal fragments of seven housekeeping genes ( $g l t A, g y r B, g d h B, r e c A, c p n 60$, gpi and $r p o D)$ were amplified by PCR (49). The sequences of the seven housekeeping genes were compared with existing sequences in the 
Table II. Susceptibilities to two types of aminoglycosides of A. baumannii isolates.

\begin{tabular}{|c|c|c|c|c|}
\hline Drug name & Resistant isolates, n (\%) & Intermediate isolates, $\mathrm{n}(\%)$ & Sensitive isolates, $\mathrm{n}(\%)$ & Total, n (\%) \\
\hline Gentamicin & $73(61.86)$ & $3(2.54)$ & $42(35.60)$ & $118(100)$ \\
\hline Amikacin & $72(61.02)$ & $0(0.00)$ & $46(38.98)$ & $118(100)$ \\
\hline
\end{tabular}

MLST database (50) for the assignment of allelic numbers. Sequence types (STs) were assigned according to their allelic profiles. New allele sequences and STs were assigned in accordance with the PubMLST database (50). The eBURST program (http://eburst.mlst.net) was used to cluster STs into clonal complex (CC) and infer evolutionary descent (51).

\section{Results}

Antimicrobial susceptibility of aminoglycosides. All 118 clinical strains were identified as A. baumannii by $16 \mathrm{~S}$ rRNA and recA amplification. Among these isolates, $73(61.86 \%)$ and $72(61.02 \%)$ strains were resistant to gentamicin and amikacin, respectively (Tables II and III). Thus, the resistance to amikacin and gentamicin was observed in $66(55.93 \%, 66 / 118)$ A. baumannii isolates. A total of $78(66.1 \%, 78 / 118)$ isolates were resistant to amikacin and gentamicin, and $75(96.15 \%$, $75 / 78$ ) of the strains showed a high level of resistance (MIC, $\geq 256 \mu \mathrm{g} / \mathrm{ml}$; Table III).

Co-occurrence of aminoglycoside-resistant enzymes and carbapenemases. To determine the role of the aminoglycoside-modifying enzymes in resistance and the $16 \mathrm{~S}$ rRNA methylases, PCR was performed to detect the concomitant genes (Table III). The positive rates of ant(2")-Ia, aac(6')-Ib, aph(3')-Ia, $\operatorname{aac}(3)-I a$ and $\operatorname{aac}(3)-I I a$ were 66.95 (79/118), 69.49 (82/118), 42.37 (50/118), 39.83 (47/118) and 14.41\% (17/118), respectively (Table IV). Fifty-four of $118(45.76 \%)$ isolates harboring the $16 \mathrm{~S}$ rRNA methyalse $\mathrm{armA}$ gene obtained high level of resistance to amikacin and gentamicin. $r m t A, r m t B$, $r m t C, r m t D, r m t E, r m t F, r m t G$ and $n p m A$ genes were not detected in all of the isolates.

There was a marked difference in the distribution of aminoglycoside-resistant genes among the 75 high-level aminoglycoside-resistant $A$. baumannii (Tables III and IV). All $54(72.0 \%, 54 / 75)$ armA-positive strains were confirmed to serve a primary role in high level aminoglycoside resistance. However, $21(28 \%, 21 / 75)$ isolates harboring aminoglycoside-modifying enzymes without the $\operatorname{arm} A$ gene served the same function (Table V).

Among the 54 isolates that were $\operatorname{armA-positive,~the~}$ prevalence of $b l a_{\text {OXA-23 }}$ and $b l a_{\text {OXA-51 }}$ gene occurrences were $79.63(43 / 54)$ and $100 \%(54 / 54)$, respectively. In addition, the prevalence of $\operatorname{ant}\left(2^{\prime \prime}\right)-I a, \operatorname{aac}\left(6^{\prime}\right)-I b, \operatorname{aph}\left(3^{\prime}\right)-I a, \operatorname{aac}(3)-I a$, and $\operatorname{aac}(3)-I I a$ positive rates of genes was distributed in the aminoglycoside-resistant and-susceptible strains (Table V). As described above, the present study demonstrated that aminoglycoside-modifying enzymes were mostly responsible for moderate level resistance $(16 \mu \mathrm{g} / \mathrm{ml}<\mathrm{MIC}<256 \mu \mathrm{g} / \mathrm{ml})$ to aminoglycosides in $A$. baumannii, whereas $\operatorname{arm} A$ was responsible for high-level resistance to aminoglycosides.
All 75 isolates with high-level resistance to aminoglycosides harbored the carbapenemase genes $b l a_{\text {OXA-23 }}(77.33 \%)$ or $b l a_{\text {OXA-51 }}$ (100\%; Tables III and V), which (except one isolate) showed resistance to the carbapenems, imipenem and meropenem. These data suggest that the resistance to carbapenems and aminoglysides poses a threat following combination treatment of A. baumannii infection.

Molecular genotyping analysis of drug-resistant isolates. To better assess the A. baumannii clinical population epidemiology and the genetic background of these strains, a number of molecular typing systems were applied. By comparing the ST(s) of 75 high-level aminoglycoside resistant isolates with all identified ST(s) in A. baumannii in the MLST database by eBUSRT analysis, 29 strains were identified that belonged to ST92, which is a globally distributed strain (Fig. 1A). According to MLST analysis, a total of 31 different STs were assigned to the 75 high-level aminoglycoside resistant isolates, of which 21 STs were clustered into clonal complex 92 (CC92), and the remaining 10 STs were identified as singletons. The most common ST was ST92, which accounted for $38.67 \%$ (29/75) (Fig. 1A and B). ST195, followed by ST92, presented in 5 strains, whilst ST136 and ST843 were detected in 4 strains. ST75, ST829, ST837, ST899, ST909 and ST916 were represented by 2 isolates. Molecular analysis revealed that 37 (containing 6 different STs) of the 43 isolates, which produced carbapenemase OXA-23 and 16S rRNA methylase ArmA, were grouped into $\mathrm{CC} 92$, while the remaining 6 isolates, which had 6 different STs, could not be clustered into any known clonal complex (Fig. 1C). These data indicate that the prevalence of $A$. baumannii isolates was caused by CC92 dissemination.

\section{Discussion}

A. baumannii are important hospital-acquired pathogens that cause various types of human infections (52). The present study demonstrated that $75(63.56 \%)$ strains were high-level resistant to amikacin or gentamicin, determined by susceptibility testing (Table III), suggesting that these antibiotics can only be used for treating A. baumannii infections induced by susceptible strains.

As indicated above, at least one aminoglycoside resistance gene was detected in aminoglycoside-resistant A. baumannii strains, and different resistant genes were commonly present in the same isolates (Tables III and V). Among these strains, the dominant aminoglycoside-resistant genotypes are ant(2")-Ia, $\operatorname{armA}$ and $a a c\left(6^{\prime}\right)-I b$, which were present at 66.95, 45.76 and $69.49 \%$, respectively (Table IV). These results indicated that the presence of armA and aminoglycoside-modifying enzmyes confers to the high level of aminoglycoside resistance. 


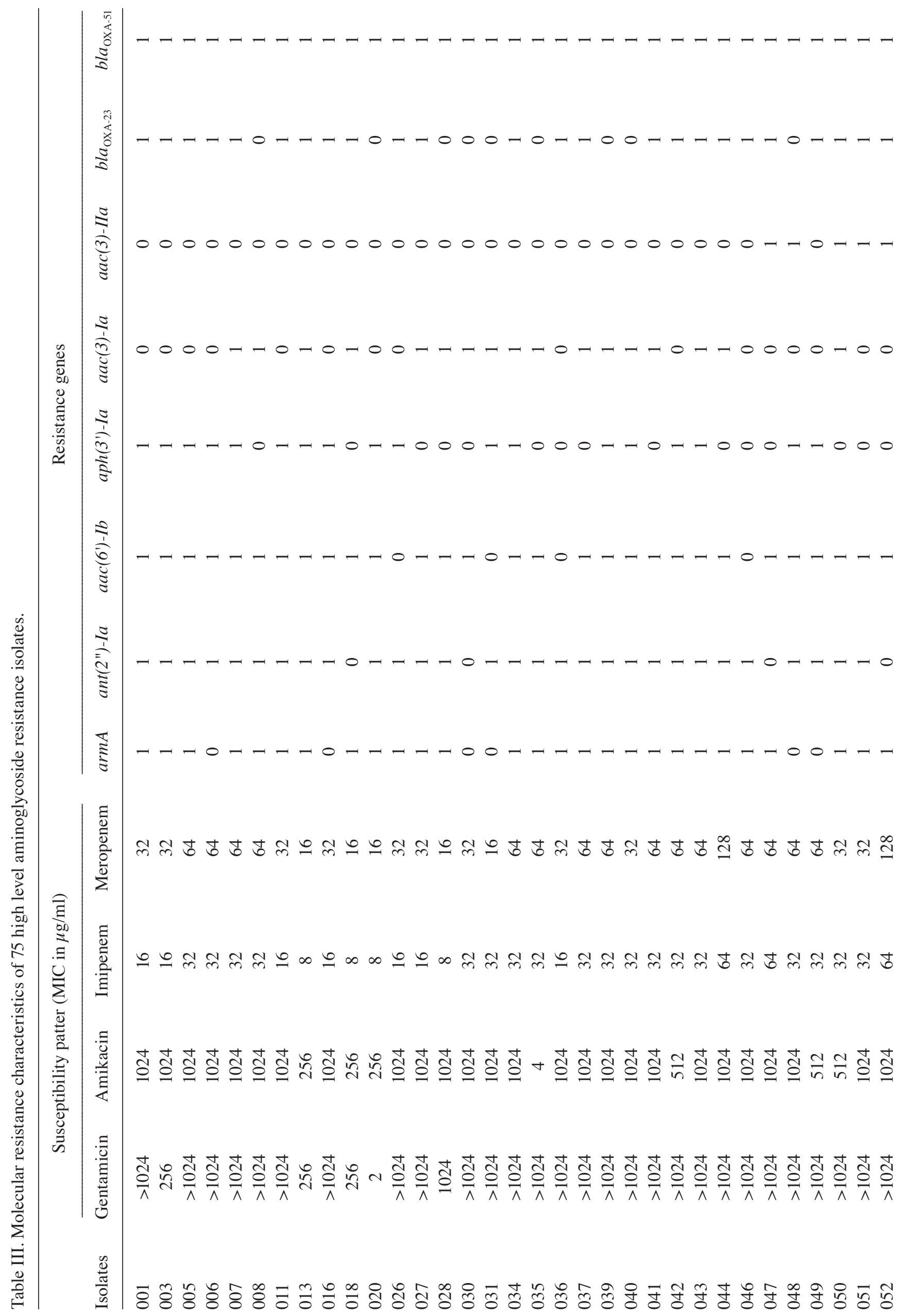




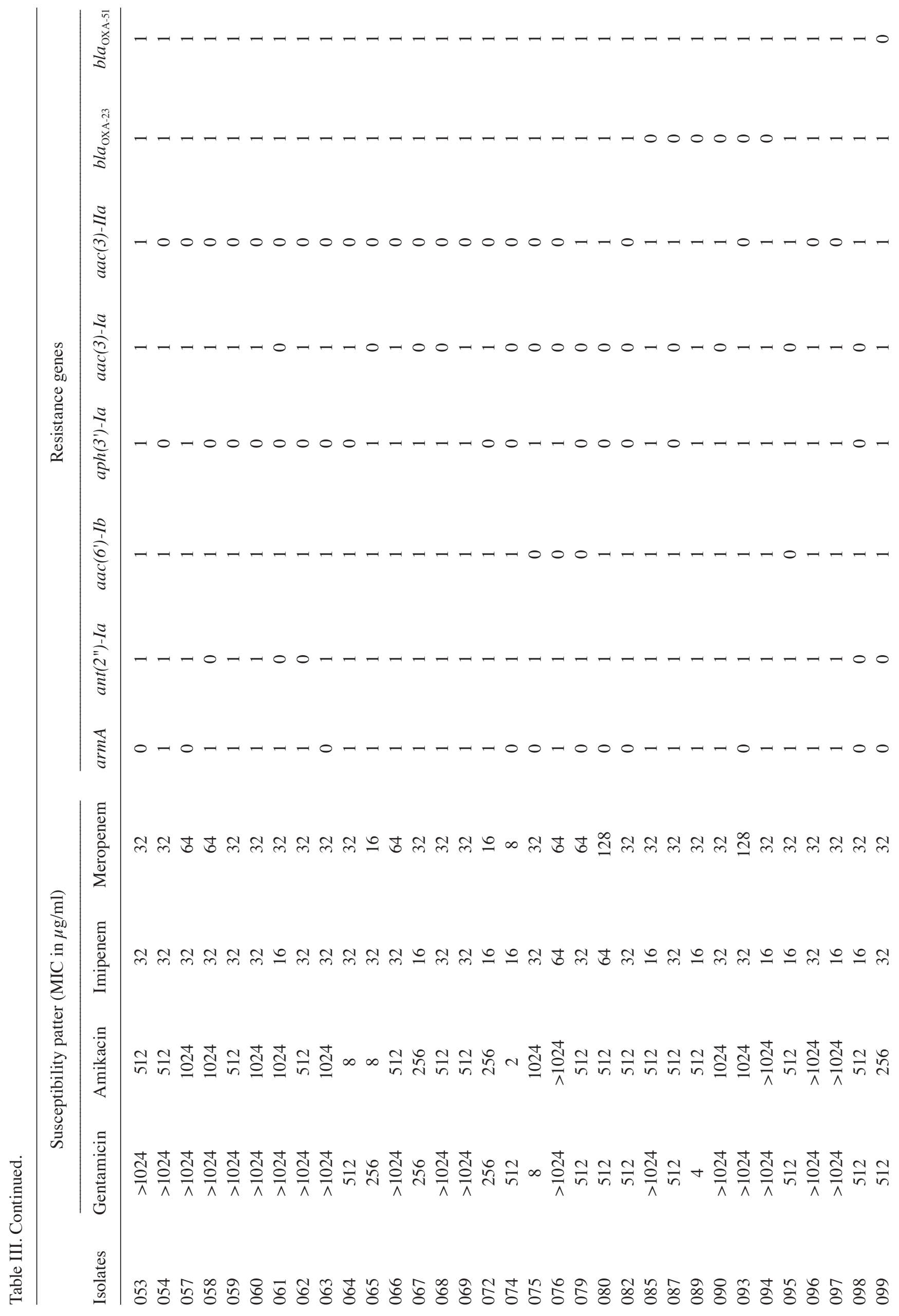




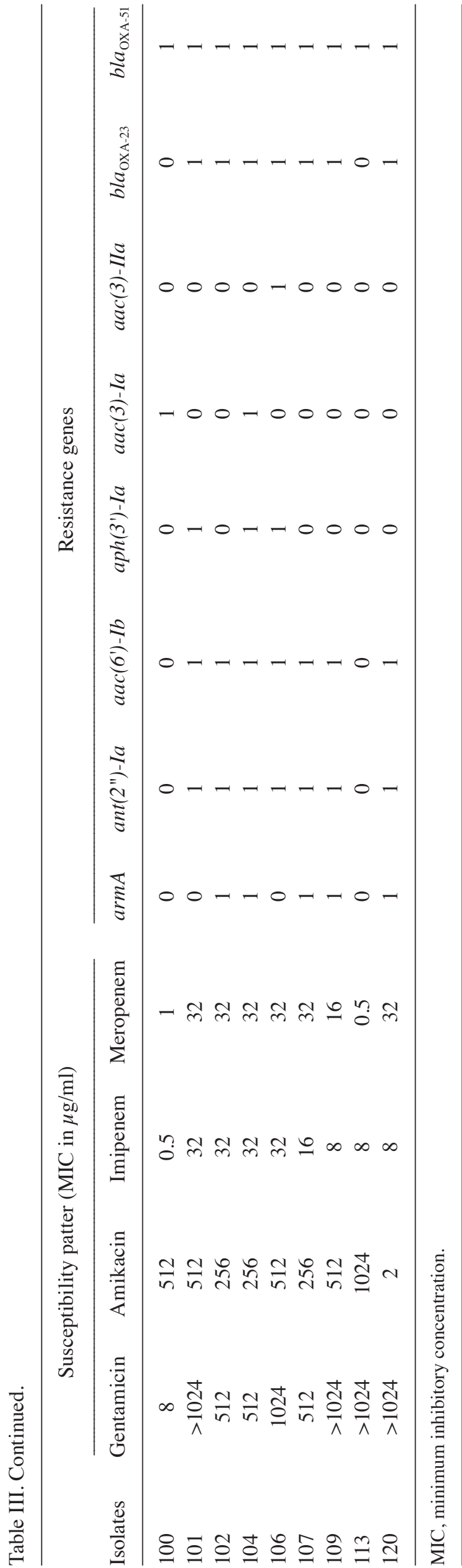

The prevalence of armA genes in A. baumannii isolates has been described in several studies that showed 50\% (52/104) in strains isolated in Lishui, eastern China (10), 60.4\% (61/101) in clinical strains in Vietnam (53), and 59.54\% (103/173) in hospitals in Beijing, China (54). In the present study, $45.76 \%$ (54/118, Table IV) of isolates harbored the armA gene, which is similar to the above cases reported in China. In addition, it was reported that $\operatorname{armA}$ was identified in 90\% (97/107) of the multidrug-resistant strains in Shanghai, eastern China (55). In a previous study, however, $4(8.5 \%)$ isolates were positive for the methylase enzyme ArmA in an Algerian hospital (56). In conclusion, $\operatorname{armA}$ is highly prevalent worldwide, particularly in China.

The emergence of high level aminoglycoside resistance may pose a question for the combination therapy of aminoglycoside with $\beta$-lactams, particularly carbapenems in treating A. baumannii infections. Previously, A. baumannii producing OXA-23 have been increasingly described in Shanghai, eastern China (38). Thus, the present study identified carbapenemase genes in 75 high-level aminoglycoside resistance strains. The positive ratios of $b l a_{\mathrm{OXA}-51}$ and $b l a_{\mathrm{OXA}-23}$ were 100 (75/75) and 77.33\% (58/75), respectively (Table III), further demonstrating that the intrinsic OXA-51 family and the presence of OXA-23 are the most prevalent mechanisms for carbapenem resistance in A. baumannii (57). In addition, among $54 \operatorname{arm} A$-positive isolates, the prevalence of $b l a_{\text {OXA-23 }}$ and $b l a_{\text {OXA-51 }}$ were 79.63 (43/54) and 100\% (54/54) (Table V), which was similar to a previous study $(27,56)$. Three hospital disseminations of $A$. baumannii co-producing OXA-23 and ArmA were reported in eastern China in 2009 and $2011(21,34,35)$. To the best of our knowledge, the results in the present study are the first to demonstrate the co-occurrence of carbapenemases OXA-23, OXA-51 and 16S rRNA methylase ArmA with high level aminoglycoside resistance among clinical isolates of $A$. baumannii from Chengdu, western China.

Previously, it was reported that aminoglycosides with the aaclaad riboswitch control the expression of aminoglycoside modification enzymes (58), indicating that bacteria can survive in an energy saving way. Therefore, these efficient modification enzymes were responsible for aminoglycoside resistance (Table IV). In addition, it was identified that the $a a c\left(6^{\prime}\right)-I b$ enzyme is able to modify amikacin, even in phenotypically amikacin-susceptible isolates (59). Furthermore, the $a a c\left(6^{\prime}\right)-I b$ (69.49\%) A. baumannii isolates were aminoglycoside-positive (Table IV), which is different from previous studies (10). The reason why these differences were observed may be due to the resistance level caused by $a a c\left(6^{\prime}\right)-I b$, which was regional-dependent and host bacterium-dependent (59).

In the present study, a higher rate of aac(3)-IIa (14.41\%) were detected. In addition, aac(3)-II a genes were detected in $47.88 \%$ of $E$. coli isolated from an Iranian hospital (60). Miro et al (61) found $12.4 \%$ of strains possessing aac(3)-IIa genes. However, there is a paucity of data regarding the aac(3)-IIa gene distribution in A. baumannii. It was reported that only 4 strains (3.7\%) carried aac(3)-IIa genes (62); aac(3)-IIa was not identified in any strains in a study by Nowak et al (63). Previous studies have reported that aac(3)-IIa modifies gentamicin, which explains the observed high rate of resistance to gentamicin in these A. baumannii 
Table IV. Positive rates of genes in A. baumannii.

\begin{tabular}{lccr}
\hline Gene & Positive rate, \% (n/118) & Gene & Positive rate, \% (n/118) \\
\hline armA & $45.76(54 / 118)$ & $\operatorname{aph}\left(3^{\prime}\right)-I a$ & $42.37(50 / 118)$ \\
$\operatorname{aac}\left(6^{\prime}\right)-I b$ & $69.45(82 / 118)$ & $\operatorname{aac}(3)-I a$ & $39.83(47 / 118)$ \\
ant(2")-la & $66.95(79 / 118)$ & $\operatorname{aac}(3)-I I a$ & $14.41(17 / 118)$ \\
\hline
\end{tabular}

Table V. Distribution of aminoglycoside resistance genes in 75 high level aminoglycoside resistance clinical isolates of A. baumannii, expressed as positive (+) or negative (-).

\begin{tabular}{|c|c|c|c|}
\hline $\begin{array}{l}\operatorname{armA-positive~aminoglycoside~resistance~gene~profile~} \\
(\mathrm{n}=54)\end{array}$ & $\begin{array}{l}\text { bla }_{\text {OXA-23 }} \\
(\mathrm{n}=58)\end{array}$ & $\begin{array}{l}\text { bla } a_{\text {OXA-51 }} \\
(\mathrm{n}=75)\end{array}$ & No. of isolates \\
\hline $\operatorname{ant}(2 ")-I a$ & +2 & + & $2(2.67 \%)$ \\
\hline$a a c\left(6^{\prime \prime}\right)-I b$ & +1 & + & $1(1.33 \%)$ \\
\hline $\operatorname{ant}\left(2^{\prime \prime}\right)-I a+a a c\left(6^{\prime}\right)-I b$ & +4 & + & $4(5.33 \%)$ \\
\hline $\operatorname{ant}\left(2^{\prime \prime}\right)-I a+\operatorname{aph}\left(3^{\prime}\right)-I a$ & +2 & + & $2(2.67 \%)$ \\
\hline$a a c\left(6^{\prime}\right)-I b+a a c(3)-I a$ & +3 & + & $3(4.0 \%)$ \\
\hline$a a c\left(6^{\prime}\right)-I b+a a c(3)-I I a$ & +2 & + & $2(2.67 \%)$ \\
\hline$a n t\left(2^{\prime \prime}\right)-I a+a a c\left(6^{\prime}\right)-I b+a a c(3)-I a$ & $+9 /-3$ & + & $12(16 \%)$ \\
\hline$a n t\left(2^{\prime \prime}\right)-I a+a a c\left(6^{\prime}\right)-I b+a a c(3)-I I a$ & $+1 /-1$ & + & $2(2.67 \%)$ \\
\hline $\operatorname{ant}\left(2^{\prime \prime}\right)-I a+a a c\left(6^{\prime}\right)-I b+a p h\left(3^{\prime}\right)-I a$ & $+9 /-1$ & + & $10(13.3 \%)$ \\
\hline $\operatorname{ant}\left(2^{\prime \prime}\right)-I a+\operatorname{aph}\left(3^{\prime}\right)-I a+\operatorname{aac}(3)-I I a$ & +1 & + & $1(1.33 \%)$ \\
\hline$a n t\left(2^{\prime \prime}\right)-I a+a a c\left(6^{\prime}\right)-I b+a p h\left(3^{\prime}\right)-I a+a a c(3)-I a$ & $+8 /-2$ & + & $10(13.3 \%)$ \\
\hline $\operatorname{ant}\left(2^{\prime \prime}\right)-I a+a a c\left(6^{\prime}\right)-I b+a p h\left(3^{\prime}\right)-I a+a a c(3)-I I a$ & -1 & + & $1(1.33 \%)$ \\
\hline$a n t\left(2^{\prime \prime}\right)-I a+a a c\left(6^{\prime}\right)-I b+a a c(3)-I a+a a c(3)-I I a$ & +1 & + & $1(1.33 \%)$ \\
\hline$a n t\left(2^{\prime \prime}\right)-I a+a a c\left(6^{\prime}\right)-I b+a p h\left(3^{\prime}\right)-I a+a a c(3)-I a+a a c(3)-I I a$ & -3 & + & $3(4.0 \%)$ \\
\hline \multicolumn{4}{|l|}{ None of armA genes (21) } \\
\hline $\operatorname{ant}(2 ")-I a$ & + & + & $1(1.33 \%)$ \\
\hline$a a c\left(6^{\prime}\right)-I b$ & - & + & $1(1.33 \%)$ \\
\hline $\operatorname{aac}\left(6^{\prime}\right)-I b+a n t\left(2^{\prime \prime}\right)-I a$ & + & + & $1(1.33 \%)$ \\
\hline$a a c\left(6^{\prime}\right)-I b+a a c(3)-I a$ & -2 & + & $2(2.67 \%)$ \\
\hline$a a c\left(6^{\prime}\right)-I b+a a c(3)-I I a$ & + & + & $1(1.33 \%)$ \\
\hline $\operatorname{ant}\left(2^{\prime \prime}\right)-I a+a a c\left(6^{\prime}\right)-I b+a p h\left(3^{\prime}\right)-I a$ & +5 & + & $5(6.67 \%)$ \\
\hline $\operatorname{ant}\left(2^{\prime \prime}\right)-I a+a a c\left(6^{\prime}\right)-I b+a a c(3)-I a$ & + & + & $1(1.33 \%)$ \\
\hline$a n t\left(2^{\prime \prime}\right)-I a+a a c\left(6^{\prime}\right)-I b+a a c(3)-I I a$ & +2 & + & $2(2.67 \%)$ \\
\hline $\operatorname{ant}\left(2^{\prime \prime}\right)-I a+\operatorname{aph}\left(3^{\prime}\right)-I a+a a c(3)-I I a$ & - & + & $1(1.33 \%)$ \\
\hline $\operatorname{ant}\left(2^{\prime \prime}\right)-I a+a a c\left(6^{\prime}\right)-I b+a p h\left(3^{\prime}\right)-I a+a a c(3)-I a$ & $+/-2$ & + & $3(4.0 \%)$ \\
\hline $\operatorname{ant}\left(2^{\prime \prime}\right)-I a+a a c\left(6^{\prime}\right)-I b+a p h\left(3^{\prime}\right)-I a+a a c(3)-I I a$ & + & + & $1(1.33 \%)$ \\
\hline$a a c\left(6^{\prime}\right)-I b+a p h\left(3^{\prime}\right)-I a+a a c(3)-I a+a a c(3)-I I a$ & + & + & $1(1.33 \%)$ \\
\hline$a n t\left(2^{\prime \prime}\right)-I a+a a c\left(6^{\prime}\right)-I b+a p h\left(3^{\prime}\right)-I a+a a c(3)-I a+a a c(3)-I I a$ & + & + & $1(1.33 \%)$ \\
\hline
\end{tabular}

strains (59). The increasing prevalence of aminoglycoside resistance is partly associated with the presence of $\operatorname{aac}\left(3^{\prime}\right)-I I a$.

The PubMLST database assigned A. baumannii strains to 920 different types. ST92, a globally distributed type, was the predicted founder of CC92 in the A. baumannii MLST database. CC92 is the largest and most geographically diverse clonal complex (64). Combined ST profiles from MLST and eBURST analyses showed that almost all isolates were clonally related and CC92 was responsible for the spread of disease (Fig. 1). The present study further suggests the possibility that
A. baumannii carrying bla $a_{\mathrm{OXA}-23}$ and $\operatorname{armA}$ genes contribute towards CC92 dissemination. In addition, the present study described the emergence and spread of a clonal strain of the high-level aminoglycoside-resistant $A$. baumannii. These findings support the hypothesis that certain restricted genetic backgrounds serve an important role in the emergence of aminoglycoside resistance, since some genetic backgrounds may be prone to acquire a foreign resistance gene and maintain its stability and expression (46). Further analysis of the epidemiology of A. baumannii is required in order to determine the prevalence of drug-resistant genes. 
A

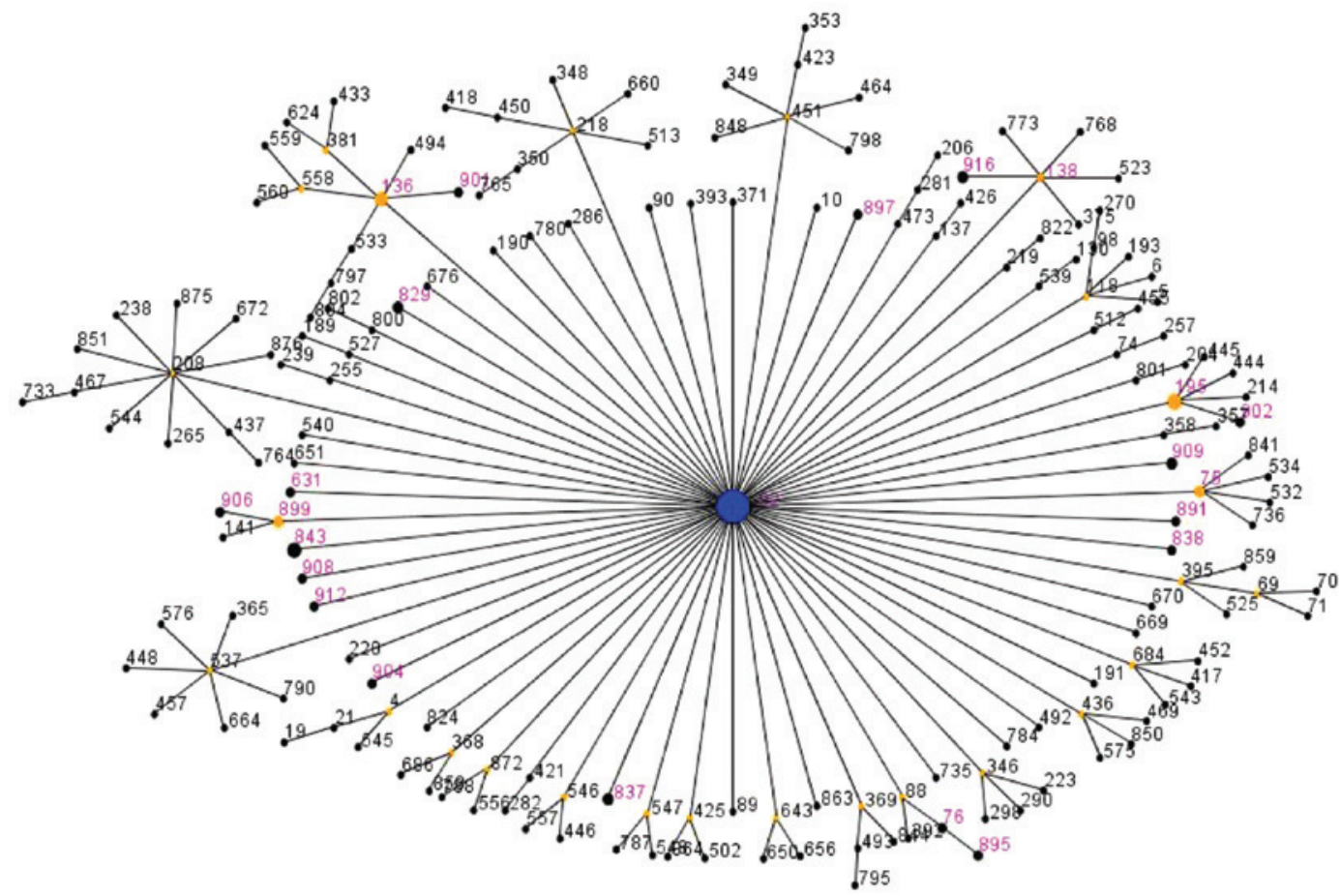

B

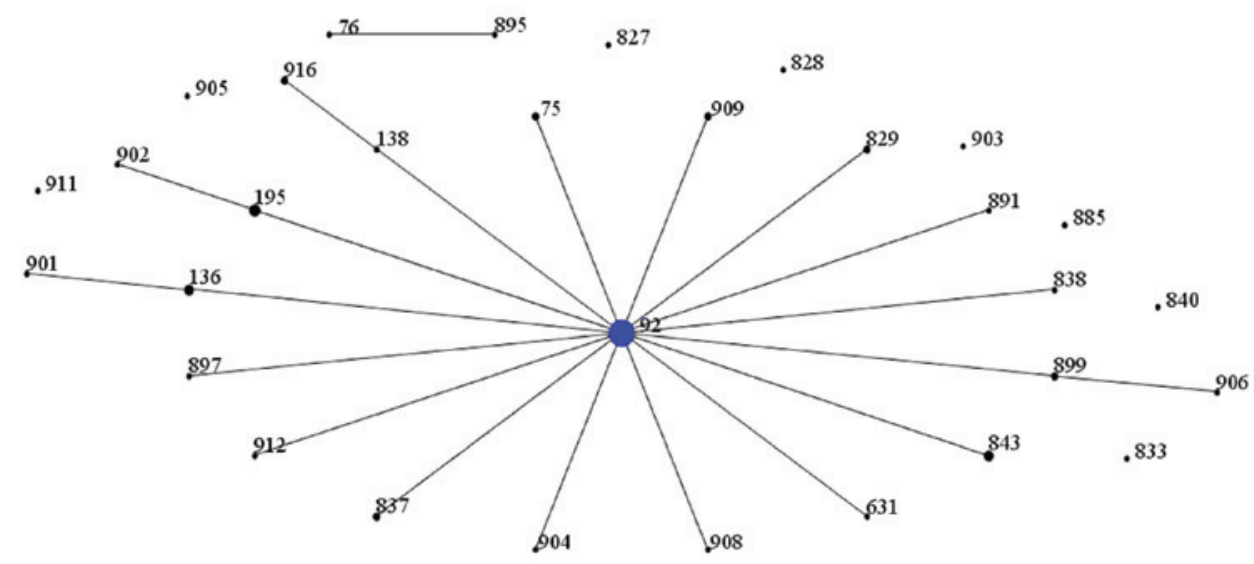

C

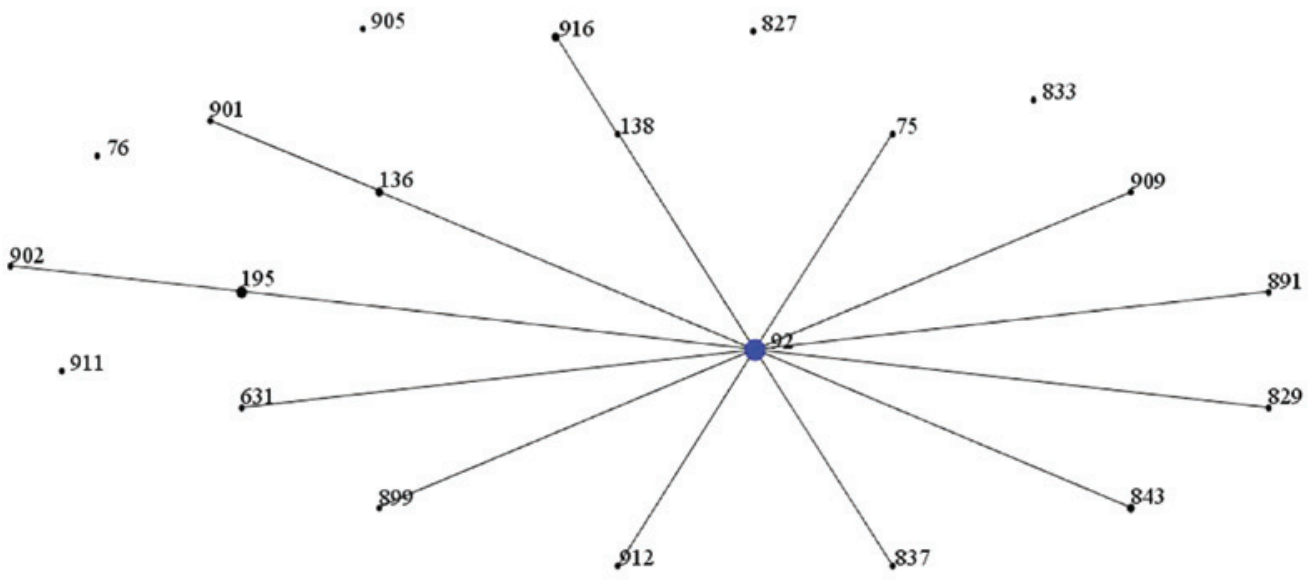

Figure 1. Relatedness of the STs of 75 high-level aminoglycoside resistance strains. Each circle represents a specific ST. The size of each circle corresponds to number of isolates, with larger sizes representing higher frequency of occurrence. The blue dot in the center corresponds to ST92, the most prevalent. Black numbers indicate existence of STs in the MLST database, and the numbers in purple indicate STs found in the present study. (A) eBURST population snapshot of CC92. Six was used as the minimum identical loci for the definition of CC and three was used as the minimum single locus variants. (B) Similar population snapshot pictures and superscript pictures. Similar population snapshot pictures were drawn by eBURST algorithm of Acinetobacter baumannii STs in the PubMLST database, and superscript pictures were analyzed through the University of Oxford database. (C) The relatedness of the STs of 43 A. baumannii strains carrying $b l a_{\mathrm{OXA}-23}$ and $\operatorname{armA}$ genes. The radial diagram reflects the predicted evolutionary descent from the founder ST. The size of the circle corresponds to the number of isolates belonging to a ST. STs, sequence types; CC, clonal complex. 
In conclusion, the present study demonstrated that $16 \mathrm{~S}$ rRNA methylase ArmA and modifying enzyme occurrence confer high level resistance to aminoglycoside in A. baumannii. In addition, it was identified that the high level aminoglycoside resistance of A. baumannii strains, harboring high percentages of positive carbapenemases $b l a_{\text {OXA-23 }}$ and bla $a_{\text {OXA-51 }}$, strongly suggest that a better understanding of the global epidemiology and monitoring for the presence of resistance genes is urgently required.

\section{Acknowledgments}

The authors would like to thank members of the Key Laboratory of Non Coding RNA and Drug Discovery, the Education Department of Sichuan Province, Chengdu, China for their input. The present study was supported by grants from the National Natural Science Foundation of China (grant nos. 81373454, 31300659, 31470246 and 31401099), Applied Basic Research Programs of Sichuan Province, China (grant no. 2013jy0065) Scientific Research and Innovation Team of Sichuan Province, China (grant no. 15TD0025) and the Preeminent Youth Fund of Sichuan Province, China (grant no. 2015JQO019).

\section{References}

1. Sheikh YA, Marie MA, John J, Krishnappa LG and Dabwab KH: Prevalence of 16S rRNA methylase genes among $\beta$-lactamase-producing Enterobacteriaceae clinical isolates in Saudi Arabia. Libyan J Med 9: 24432, 2014.

2. Belbel Z, Chettibi H, Dekhil M, Ladjama A, Nedjai S and Rolain JM: Outbreak of an armA Methyltransferase-Producing ST39 Klebsiella pneumoniae clone in a pediatric Algerian hospital. Microb Drug Resist 20: 310-315, 2014.

3. Liu Z, Ling B and Zhou L: Prevalence of 16S rRNA methylase, modifying enzyme, and extended-spectrum beta-lactamase genes among Acinetobacter baumannii isolates. J Chemother 27: 207-212, 2015.

4. Nemec A, Dolzani L, Brisse S, van den Broek P and Dijkshoorn L: Diversity of aminoglycoside-resistance genes and their association with class 1 integrons among strains of pan-European Acinetobacter baumannii clones. J Med Microbiol 53: 1233-1240, 2004.

5. Labby KJ and Garneau-Tsodikova S: Strategies to overcome the action of aminoglycoside-modifying enzymes for treating resistant bacterial infections. Future Med Chem 5: 1285-1309, 2013.

6. Ramirez MS and Tolmasky ME: Aminoglycoside modifying enzymes. Drug Resist Updat 13: 151-171, 2010.

7. Cho YJ, Moon DC, Jin JS, Choi CH, Lee YC and Lee JC: Genetic basis of resistance to aminoglycosides in Acinetobacter spp. and spread of armA in Acinetobacter baumannii sequence group 1 in Korean hospitals. Diagn Microbiol Infect Dis 64: 185-190, 2009

8. Bueno MF, Francisco GR, O'Hara JA, de Oliveira Garcia D and Doi Y: Coproduction of 16S rRNA methyltransferase RmtD or RmtG with KPC-2 and CTX-M group extended-spectrum $\beta$-lactamases in Klebsiella pneumoniae. Antimicrob Agents Chemother 57: 2397-2400, 2013.

9. Galimand $\mathrm{M}$, Courvalin $\mathrm{P}$ and Lambert $\mathrm{T}$ : RmtF, a new member of the aminoglycoside resistance 16S rRNA N7 G1405 methyltransferase family. Antimicrob Agents Chemother 56: 3960-3962, 2012.

10. Huang J, Ye M, Jia X, Yu F and Wang M: Coexistence of armA and genes encoding aminoglycoside-modifying enzymes in Acinetobacter baumannii. Afr J Microbiol Res 6: 5325-5330, 2012.

11. O'Hara JA, McGann P, Snesrud EC, Clifford RJ, Waterman PE, Lesho EP and Doi Y: Novel 16S rRNA methyltransferase RmtH produced by Klebsiella pneumoniae associated with war-related trauma. Antimicrob Agents Chemother 57: 2413-2416, 2013.

12. Wachino J and Arakawa Y: Exogenously acquired 16S rRNA methyltransferases found in aminoglycoside-resistant pathogenic Gram-negative bacteria: An update. Drug Resist Updat 15: 133-148, 2012.
13. Wachino J, Shibayama K, Kurokawa H, Kimura K, Yamane K, Suzuki S, Shibata N, Ike Y and Arakawa Y: Novel plasmid-mediated 16S rRNA m1A1408 methyltransferase, NpmA, found in a clinically isolated Escherichia coli strain resistantto structurally diverse aminoglycosides. Antimicrob Agents Chemother 51: 4401-4409, 2007.

14. Nagasawa M, Kaku M, Kamachi K, Shibayama K, Arakawa Y, Yamaguchi K and Ishii Y: Loop-mediated isothermal amplification assay for 16S rRNA methylase genes in Gram-negative bacteria. J Infect Chemother 20: 635-638, 2014.

15. Marques MB, Brookings ES, Moser SA, Sonke PB and Waites KB: Comparative in vitro antimicrobial susceptibilities of nosocomial isolates of Acinetobacter baumannii and synergistic activities of nine antimicrobial combinations. Antimicrob Agents Chemother 41: 881-885, 1997.

16. Wen JT, Zhou Y, Yang L and Xu Y: Multidrug-resistantgenes of aminoglycoside-modifying enzymes and 16S rRNA methylases in Acinetobacter baumannii strains. Genet Mol Res 13: 3842-3849, 2014

17. Chang Y, Luan G, Xu Y, Wang Y, Shen M, Zhang C, Zheng W, Huang J, Yang J, Jia $X$ and Ling B. Characterization of carbapenem-resistant Acinetobacter baumannii isolates in a Chinese teaching hospital. Front Microbiol 6: 910, 2015.

18. Walther-Rasmussen J and Høiby N: OXA-type carbapenemases. J Antimicrob Chemother 57: 373-383, 2006.

19. Doi Y, Adams JM, Yamane K and Paterson DL: Identification of 16S rRNA methylase-producing Acinetobacter baumannii clinical strains in North America. Antimicrob Agents Chemother 51: 4209-4210, 2007

20. Kim JW, Heo ST, Jin JS, Choi CH, Lee YC, Jeong YG, Kim SJ and Lee JC: Characterization of Acinetobacter baumannii carrying bla(OXA-23), bla(PER-1) and armA in a Korean hospital. Clin Microbiol Infect 14: 716-718, 2008.

21. Zhou H, Du XX, Yang Q, Zhou JY, Yu YS and Li LJ: Study on carbapenemase and 16S rRNA methylase of imipenem-resistant Acinetobacter baumannii. Zhonghua Liu Xing Bing Xue Za Zhi 30: 269-272, 2009 (In Chinese).

22. Adams-Haduch JM, Paterson DL, Sidjabat HE, Pasculle AW, Potoski BA, Muto CA, Harrison LH and Doi Y: Genetic basis of multidrug resistance in Acinetobacter baumannii clinical isolates at a tertiary medical center in Pennsylvania. Antimicrob Agents Chemother 52: 3837-3843, 2008.

23. Sung JY, Kwon KC, Cho HH and Koo SH: Antimicrobial resistance determinants in imipenem-nonsusceptible Acinetobacter calcoaceticus-baumannii complex isolated in Daejeon, Korea. Korean J Lab Med 31: 265-270, 2011.

24. Karthikeyan K, Thirunarayan MA and Krishnan P: Coexistence of blaOXA-23 with blaNDM-1 and armA in clinical isolates of Acinetobacter baumannii from India. J Antimicrob Chemother 65: 2253-2254, 2010.

25. Bonnin RA, Potron A, Poirel L, Lecuyer H, Neri R and Nordmann P: PER-7, an extended-spectrum beta-lactamase with increased activity toward broad-spectrum cephalosporins in Acinetobacter baumannii. Antimicrob Agents Chemother 55: 2424-2427, 2011.

26. Strateva T, Markova B, Marteva-Proevska Y, Ivanova D and Mitov I: Widespread dissemination of multidrug-resistant Acinetobacter baumannii producing OXA-23 carbapenemase and ArmA 16 S ribosomal RNA methylase in a Bulgarian university hospital. Braz J Infect Dis 16: 307-310, 2012.

27. Brigante G, Migliavacca R, Bramati S, Motta E, Nucleo E, Manenti M, Migliorino G, Pagani L, Luzzaro F and Viganò FE: Emergence and spread of a multidrug-resistant Acinetobacter baumannii clone producing both the carbapenemase OXA-23 and the 16S rRNA methylase ArmA. J Med Microbiol 61: 653-661, 2012.

28. Saule M, Samuelsen Ø, Dumpis U, Sundsfjord A, Karlsone A, Balode A, Miklasevics E and Karah N: Dissemination of a carbapenem-resistant Acinetobacter baumannii strain belonging to international clone II/sequence type 2 and harboring a novel AbaR4-like resistance island in Latvia. Antimicrob Agents Chemother 57: 1069-1072, 2013.

29. Revathi G, Siu LK, Lu PL and Huang LY: First report of NDM-1-producing Acinetobacter baumannii in East Africa. Int J Infect Dis 17: e1255-e1258, 2013.

30. Bakour S, Alsharapy SA, Touati A and Rolain JM: Characterization of Acinetobacter baumannii clinical isolates carrying bla(OXA-23) carbapenemase and $16 \mathrm{~S}$ rRNA methylase armA genes in Yemen. Microb Drug Resist 20: 604-609, 2014 
31. Tada T, Miyoshi-Akiyama T, Shimada K, Shimojima M and Kirikae T: Dissemination of $16 \mathrm{~S}$ rRNA methylase ArmA-producing Acinetobacter baumannii and emergence of OXA-72 carbapenemase coproducers in Japan. Antimicrob Agents Chemother 58: 2916-2920, 2014.

32. Tojo M, Mawatari M, Hayakawa K, Nagamatsu M, Shimada K, Mezaki K, Sugiki Y, Kuroda E, Takeshita N, Kutsuna S, et al: Multidrug-resistant Acinetobacter baumannii isolated from a traveler returned from Brunei. J Infect Chemothe 21: 212-214, 2015

33. El-Sayed-Ahmed MA, Amin MA, Tawakol WM, Loucif L, Bakour S and Rolain JM: High prevalence of bla(NDM-1) carbapenemase-encoding gene and 16S rRNA armA methyltransferase among Acinetobacter baumannii clinical isolates, Egypt. Antimicrob Agents Chemother 59: 3602-3605, 2015.

34. Zhao WS, Liu GY, Mi ZH and Zhang F: Coexistence of blaOXA-23 with armA and novel gyrA mutation in a pandrug-resistant Acinetobacter baumannii isolate from the blood of a patient with haematological disease in China. J Hosp Infect 77: 278-279, 2011

35. Zhou H, Zhang T, Yu D, Pi B, Yang Q, Zhou J, Hu S and $\mathrm{Yu} Y$ : Genomic analysis of the multidrug-resistant Acinetobacter baumannii strain MDR-ZJ06 widely spread in China. Antimicrob Agents Chemother 55: 4506-4512, 2011

36. Liu Z, Ling B and Zhou L: Prevalence of $16 \mathrm{~S}$ rRNA methylase, modifying enzyme, and extended-spectrum beta-lactamase genes among Acinetobacter baumannii isolates. J Chemother 27: 207-212, 2015

37. Chen TL, Siu LK, Wu RC, Shaio MF, Huang LY, Fung CP, Lee CM and Cho WL: Comparison of one-tube multiplex PCR, automated ribotyping and intergenic spacer (ITS) sequencing for rapid identification of Acinetobacter baumannii. Clin Microbiol Infect 13: 801-806, 2007.

38. Li Y, Guo Q, Wang P, Zhu D, Ye X, Wu S and Wang M: Clonal dissemination of extensively drug-resistant Acinetobacter baumannii producing an OXA-23 $\beta$-lactamase at a teaching hospital in Shanghai, China. J Microbiol Immunol Infect 48: 101-108, 2015.

39. Clinical and Laboratory Standards Institute: Performance Standards for Antimicrobial Susceptibility Testing. 24th Informational Supplement. CLSI, Wayne, PA, USA, M100, 2014.

40. Li Y, Guo Q, Wang P, Zhu D, Ye X, Wu S and Wang M: Clonal dissemination of extensively drug-resistant Acinetobacter baumannii producing an OXA-23 $\beta$-lactamase at a teaching hospital in Shanghai, China. J Microbiol Immunol Infect 48: 101-108, 2015.

41. Valenzuela JK, Thomas L, Partridge SR, van der Reijden T, Dijkshoorn L and Iredell J: Horizontal gene transfer in a polyclonal outbreak of carbapenem-resistant Acinetobacter baumannii. J Clin Microbiol 45: 453-460, 2007.

42. Tsakris A, Pournaras S, Woodford N, Palepou MF, Babini GS, Douboyas J and Livermore DM: Outbreak of infections caused by Pseudomonas aeruginosa producing VIM-1 carbapenemase in Greece. J Clin Microbiol 38: 1290-1292, 2000.

43. Ellington MJ, Kistler J, Livermore DM and Woodford N: Multiplex PCR for rapid detection of genes encoding acquired metallo-beta-lactamases. J Antimicrob Chemother 59: 321-322, 2007.

44. Yong D, Toleman MA, Giske CG, Cho HS, Sundman K, Lee K and Walsh TR: Characterization of a new metallo-beta-lactamase gene, bla(NDM-1) and a novel erythromycin esterase gene carried on a unique genetic structure in Klebsiella pneumoniae sequence type 14 from India. Antimicrob Agents Chemother 53 5046-5054, 2009.

45. Woodford N, Ellington MJ, Coelho JM, Turton JF, Ward ME, Brown S, Amyes SG and Livermore DM: Multiplex PCR for genes encoding prevalent OXA carbapenemases in Acinetobacte spp. Int J Antimicrob Agents 27: 351-353, 2006.

46. Fu Y, Zhou J, Zhou H, Yang Q, Wei Z, Yu Y and Li L: Wide dissemination of OXA-23-producing carbapenem-resistant Acinetobacter baumannii clonal complex 22 in multiple cities of China. J Antimicrob Chemother 65: 644-650, 2010.

47. Netsvyetayeva I, Sikora M, Golas M, Swoboda-Kopec E, de Walthoffen SW, Dembicka O, Fraczek M, Mlynarczyk A, Pacholczyk M, Chmura A and Mlynarczyk G: Acinetobacter baumannii multidrug-resistant strain occurrence in liver recipients with reference to other high-risk groups. Transplant Proc 43: 3116-3120, 2011.
48. Diancourt L, Passet V, Nemec A, Dijkshoorn L and Brisse S. The population structure of Acinetobacter baumannii: Expanding multiresistant clones from an ancestral susceptible genetic pool. PLoS One 5: e10034, 2010

49. Bartual SG, Seifert H, Hippler C, Luzon MA, Wisplinghoff $H$ and Rodríguez-Valera F: Development of a multilocus sequence typing scheme for characterization of clinical isolates of Acinetobacter baumannii. J Clin Microbiol 43: 4382-4390, 2005.

50. PubMLST: Acinetobacter baumannii MLST Databases. http://pubmlst.org/abaumannii/.

51. Feil EJ, Li BC, Aanensen DM, Hanage WP and Spratt BG: eBURST: Inferring patterns of evolutionary descent among clusters of related bacterial genotypes from multilocus sequence typing data. J Bacteriol 186: 1518-1530, 2004.

52. Agadzhanian VV, Semenikhin VA, Fedorov Iu S, Krasulina GP, Gay̌fulina IM and Mironova LA: Experience of health protection center on organization of medical care for coal miners in Kuzbass. Med Tr Prom Ekol: 27-30, 2002 (In Russian).

53. Tada T, Miyoshi-Akiyama T, Kato Y, Ohmagari N, Takeshita N, Hung NV, Phuong DM, Thu TA, Binh NG, Anh NQ, et al: Emergence of 16S rRNA methylase-producing Acinetobacter baumannii and Pseudomonas aeruginosa isolates in hospitals in Vietnam. BMC Infect Dis 13: 251, 2013.

54. Nie L, Lv Y, Yuan M, Hu X, Nie T, Yang X, Li G, Pang J, Zhang J, $\mathrm{Li} \mathrm{C}$, et al: Genetic basis of high level aminoglycoside resistance in Acinetobacter baumannii from Beijing, China. Acta Pharm Sin B 4: 295-300, 2014.

55. Xiao SZ, Han LZ, Chu HQ, Zhao L, Chen X and Ni YX: Detection of aminoglycoside resistance related genes in multidrug-resistant Acinetobacter baumannii isolated from a single institute of Shanghai, China. Panminerva Med 57: 49-53, 2015.

56. Bakour S, Touati A, Bachiri T, Sahli F, Tiouit D, Naim M, Azouaou M and Rolain JM: First report of 16S rRNA methylase ArmA-producing Acinetobacter baumannii and rapid spread of metallo- $\beta$-lactamase NDM-1 in Algerian hospitals. J Infect Chemother 20: 696-701, 2014.

57. Azimi L, Talebi M, Pourshafie MR, Owlia P and Rastegar Lari A: Characterization of carbapenemases in extensively drug resistance Acinetobacter baumannii in a burn care center in Iran. Int J Mol Cell Med 4: 46-53, 2015.

58. Jia X, Zhang J, Sun W, He W, Jiang H, Chen D and Murchie AI: Riboswitch control of aminoglycoside antibiotic resistance. Cell 152: 68-81, 2013.

59. Haldorsen BC, Simonsen GS, Sundsfjord A and Samuelsen $\varnothing$; Norwegian Study Group on Aminoglycoside Resistance: Increased prevalence of aminoglycoside resistance in clinical isolates of Escherichia coli and Klebsiella spp. in Norway is associated with the acquisition of $\mathrm{AAC}(3)$-II and $\mathrm{AAC}\left(6^{\prime}\right)$-Ib. Diagn Microbiol Infect Dis 78: 66-69, 2014.

60. Soleimani N, Aganj M, Ali L, Shokoohizadeh L and Sakinc T: Frequency distribution of genes encoding aminoglycoside modifying enzymes in uropathogenic E. coli isolated from Iranian hospital. BMC Res Notes 7: 842, 2014.

61. Miro E, Grünbaum F, Gomez L, Rivera A, Mirelis B, Coll P and Navarro F: Characterization of aminoglycoside-modifying enzymes in enterobacteriaceae clinical strains and characterization of the plasmids implicated in their diffusion. Microb Drug Resist 19: 94-99, 2013.

62. Akers KS, Chaney C, Barsoumian A, Beckius M, Zera W, Yu X, Guymon C, Keen EF III, Robinson BJ, Mende K and Murray CK: Aminoglycoside resistance and susceptibility testing errors in Acinetobacter baumannii-calcoaceticus complex. J Clin Microbiol 48: 1132-1138, 2010.

63. Nowak P, Paluchowska PM and Budak A: Co-occurrence of carbapenem and aminoglycoside resistance genes among multidrug-resistant clinical isolates of Acinetobacter baumannii from Cracow, Poland. Med Sci Monit Basic Res 20: 9-14, 2014

64. Hamouda A, Evans BA, Towner KJ and Amyes SG: Characterization of epidemiologically unrelated Acinetobacter baumannii isolates from four continents by use of multilocus sequence typing, pulsed-field gel electrophoresis and sequence-based typing of bla(OXA-51-like) genes. J Clin Microbiol 48: 2476-2483, 2010. 